\title{
Pengelolaan Sumberdaya Rawa Gambut dengan Pertanian Sistem Vertikultur di Desa Tanjung Taruna Kabupaten Pulang Pisau
}

\author{
(Management of Peat Swamp Resources with Agriculture of Verticulture Systems in \\ Tanjung Taruna Village, Pulang Pisau District)
}

\author{
Kevin Agus Trianto ${ }^{1}$, Wendi Setiawan ${ }^{1}$, Achmad Faried Rindhianto ${ }^{1}$ Dewi Anggrieni ${ }^{1}$, Shinta P. \\ Yuptriani $^{1}$, Riza Fahlifi ${ }^{1}$, Agung Prasetyo ${ }^{1}$, Muhammad Rizal ${ }^{1}$; Josua Situmorang ${ }^{2}$, Dhea \\ Rahmadini $^{2}$, Enrico Rafael Siahaan ${ }^{2}$, Deden Priyatna Sumantri ${ }^{2}$, Megawati Sinambela ${ }^{3}$, Rossyta \\ Aprilyani $^{3}$, Sri Endang Agustina Rahayuningsih ${ }^{1^{*}}$
}

\author{
${ }^{1}$ Program Studi Agroteknologi, Jurusan Budidaya Pertanian, Fakultas Pertanian, Universitas Palangka Raya \\ ${ }^{2}$ Program Studi Teknologi Industri Pertanian, Jurusan Budidaya Pertanian, Fakultas Pertanian, Universitas \\ Palangka Raya \\ ${ }^{3}$ Program Studi Peternakan, Jurusan Budidaya Pertanian, Fakultas Pertanian, Universitas Palangka Raya
}

*Email: agustina_rahayuningsih@agr.upr.ac.id

\begin{abstract}
Tanjung Taruna village is one of the villages in Jabiren sub-district, Pulang Pisau district, located in the lowlands, peat swamp area, and close to the Kahayan watershed. Stilt-house settlements were common in this region that built on a small area, the majority of people with an elementary to junior high school education with a livelihood are generally fishers so that their knowledge, skills, and economy still need to be improved through training and mentoring activities through the rural development grant program (PHBD) which aims to provide training and assistance that is useful for increasing knowledge, skills and welfare of the community. Methods of activities through socialization, training, and assistance on vegetable cultivation and family medicinal plants (TOGA) with verticulture systems as an alternative agricultural solution on narrow area. The verticulture systems utilize used wood, used gutter to grow plants, and a place for making organic compost. The activities showed that participation of community was quite good with numbers socialization participants were 35 people and 38 trainees. The evaluation result showed that participants' knowledge, skills, and insight increased in utilizing green plants grown in peat swamps to become organic compost used in the cultivation of vegetables and TOGA using verticulture systems to obtain additional income.
\end{abstract}

Keywords: Tanjung Taruna, peat swamp, verticulture

\begin{abstract}
Abstrak
Desa Tanjung Taruna merupakan salah satu desa di wilayah Kecamatan Jabiren, Kabupaten Pulang Pisau, terletak di daerah dalam kawasan dataran rendah, kawasan rawa gambut dan daerah aliran sungai Kahayan. Kondisi pemukiman dengan model rumah panggung dibangun pada lahan sempit, tingkat pendidikan mayoritas SD-SMP dengan mata pencaharian umumnya penangkap ikan sehingga pengetahuan, keterampilan serta perekonomiannya masih perlu ditingkatkan melalui pelatihan dan pendampingan kegiatan Program Hibah Bina Desa (PHBD) ini bertujuan untuk memberikan pelatihan dan pendampingan guna meningkatkan pengetahuan, keterampilan dan kesejahteraan masyarakat. Metode kegiatan dilakukan dengan melakukan sosialisasi, pelatihan dan pendampingan tentang budidaya sayuran dan tanaman obat keluarga (TOGA) dengan sistem vertikultur sebagai alternatif solusi pertanian pada lahan sempit. Sistem vertikultur dilakukan dengan memanfaatkan kayu-kayu bekas, talang bekas untuk dijadikan tempat bertanam, pembuatan kompos organik. Hasil kegiatan menunjukkan partisipasi peserta cukup bagus dengan jumlah peserta sosialisasi sebanyak 35 orang dan peserta pelatihan sebanyak 38 orang. Berdasarkan hasil evaluasi diketahui bahwa peserta menjadi bertambah pengetahuan,keterampilan dan wawasan dalam memanfaatkan hijau yang tumbuh di rawa gambut menjadi kompos organik yang digunakan dalam budidaya sayuran dan toga sistem vertikultur dan dapat dijadikan tambahan penghasilan untuk dijual.
\end{abstract}

Kata kunci: Tanjung Taruna, rawa gambut, vertikultur 


\section{Pendahuluan}

Desa Tanjung Taruna adalah salah satu desa di wilayah kecamatan Jabiren, kabupaten Pulang Pisau, merupakan daerah yang berada di dalam kawasan dataran rendah, kawasan rawa gambut dan aliran sungai Kahayan. Desa Tanjung Taruna berbatasan dengan desa lain dan sungai yang ada di sekitarnya, batas Barat: Kelurahan Kameloh, Sungai Teluk Putak dan KM 23 di pinggir jalan Raya, Timur: Desa Tumbang Nusa, Sungai Terusan Rahan, Utara: Desa Katunjung (Kecamatan Kapuas Barat), Kanal eksPLG, Selatan: Desa Sebangau Kuala. Jarak tempuh dari ibukota provinsi Kalimantan Tengah, kota Palangka Raya menuju ke desa Tanjung Taruna $\pm 23 \mathrm{~km}$, dengan waktu tempuh menggunakan transportasi darat selama \pm 60 menit.

Kondisi lingkungan mitra (Desa Tanjung Taruna, Kecamatan Jabiren) disajikan pada Gambar 1, dimana sarana jalan ketempat mitra hanya jalan setapak, setelah 2 KM, jalanan dengan jembatan kayu, kiri dan kanannya banyak ditumbuhi gulma-gulma air, rumah warga desa disana adalah rumah panggung kayu dengan pekarangan yang sempit sehingga untuk bercocok tanam pun sulit. Dengan kondisi geografis di daerah aliran sungai dimana membuat desa Tanjung Taruna sering terendam luapan air sungai ketika musim penghujan tiba dan ketika musim kemarau kondisi tanah menjadi keras sehingga tidak memungkinkan untuk melakukan kegiatan budidaya pertanian.

Guna memenuhi kebutuhan sayur di desa tersebut perlu adanya inovasi yang dikembangkan untuk dapat mengatasi permasalahan yang ada pada kondisi desa setempat. Desa Tanjung Taruna memiliki lahan pertanian pasang surut, meski saat ini lahan pertanian tersebut selalu digenangi air. Jenis tanah yang ada di desa Tanjung Taruna ada dua adalah tanah aluvial yang berupa tanah mineral disekitar sungai dan tanah gambut.

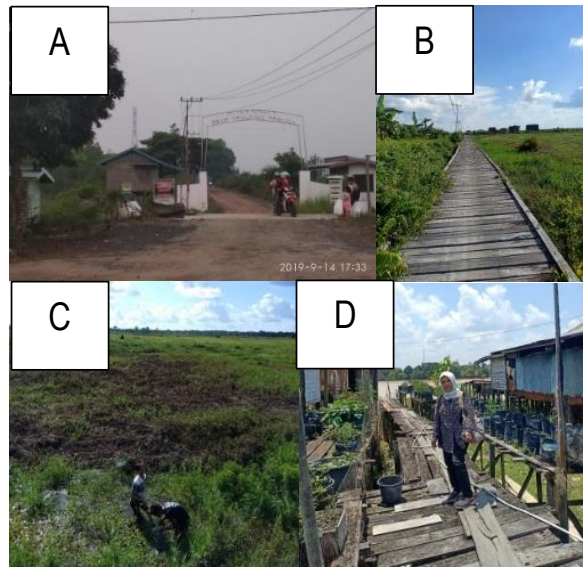

Gambar 1.

Kondisi Lingkungan Mitra. A-B. Prasaran Jalan Menuju Mitra (Desa Tanjung Taruna). C-D. Kondisi Lingkungan Desa Tanjung Taruna

Mayoritas warga Tanjung Taruna merupakan tamatan Sekolah Dasar. Mereka yang lulus sekolah perguruan tinggi atau akademi hanya sedikit. Tingkat partisipasi penduduk pada usia SD-SMP di Tanjung Taruna mencapai angka 98\%. Partisipasi masyarakat desa Tanjung Taruna dalam meningkatkan sumber daya manusia di bidang pendidikan dapat dikatakan masih rendah dikarenakan minimnya informasi masyarakat mengenai pentingnya pendidikan juga menyebabkan masyarakat tidak melanjutkan pendidikan ke jenjang yang lebih tinggi.

Berdasarkan tingkat pendidikan masyarakat desa Tanjung Taruna yang relatif masih rendah menyebabkan: 1) kurangnya pengetahuan dan keterampilan khususnya pada bidang pertanian yang bisa diterapkan di wilayahnya pada lahan yang sempit dan pada saat pasang atau musim banjir pada saat hujan, 2) kurangnya pengetahuan dalam mengelola dan memanfaatkan limbah organik seperti kotoran sapi, gulma air seperti kayambang untuk dijadikan kompos.

Tujuan kegiatan program hibah bina desa ini untuk membantu mengatasi permasalahan yang dihadapi oleh masyarakat Desa Tanjung Taruna dengan memberikan: 1) pelatihan pemanfaatan sumber daya alam yang ada seperti gulma 
air, kotoran ternak menjadi pupuk kompos dan memanfaatkan bekas sisa-sisa kayu serta talang air sebagai wadah vertikultur, 2) pendampingan teknologi budidaya tanaman toga vertikultur dan sayuran secara vertikultur (Susila, 2006; Nasrati, 2012).

\section{Metode Pelaksanaan}

\section{Waktu dan Tempat Pelaksanaan}

Jangka waktu penyelesaian kegiatan dilaksanakan selama 6 (enam) bulan, dimulai pada bulan Juni hingga November 2019 bertempat di Desa Tanjung Taruna, Kecamatan Jabiren, Kabupaten Pulang Pisau, Palangka Raya. Kegiatan sosialisasi dilakukan pada hari Selasa 27 Agustus 2019, pelatihan dilaksanakan pada hari Sabtu 14 September 2019. Evaluasi keberlanjutan program saat ini terus dilakukan hingga akhir bulan November 2019.

\section{Metode Kegiatan}

Keterlibatan mitra pada kegiatan ini adalah: kesepakatan menentukan tempat, jadual pelaksanaan kegiatan yang disesuaikan dengan waktu luang masyarakat dan berkoordinasi dengan kepala desa, perangkat desa dan masyarakat setempat (Tanjung Taruna) dan instansi terkait. Metode kegiatan berupa: 1) pelatihan pemanfaatan sumber daya alam yang ada seperti gulma air dan kotoran ternak menjadi pupuk kompos organik (Firmansyah, 2010), 2) pendampingan, pelatihan pembuatan komposisi media tanam untuk budidaya vertikultur (Trisnaningsih, 2019), 3) pendampingan, pelatihan demplot budidaya tanaman sayuran dan toga secara vertikultur dengan memanfaatkan talang air bekas, kayu bekas sebagai media tanam dan bantuan aneka bibit sayuran, pupuk NPK (16:16:16), 4) pembagian leaflet kegiatan pada peserta yang didalamnya memuat langkah kerja pembuatan kompos dan budidaya sistem vertikultur, 5) publikasi kegiatan program hibah bina Desa Tanjung Taruna melalui surat kabar dan media online.

\section{Hasil dan Pembahasan}

\section{Aktivitas Peserta}

Kegiatan pelatihan dilaksanakan di aula kantor Desa Tanjung Taruna pada hari Sabtu 14 September 2019. Peserta pelatihan yang hadir berjumlah 38 orang masyarakat/anggota PKK desa (Gambar 2), jumlah peserta yang mengikuti pelatihan ternyata jauh lebih banyak dibandingkan peserta yang hadir saat soisalisasi, ini mengindikasi minat dan atusiasme masyarakat akan kegiatan pelatihan yang diberikan, dalam kegiatan pelatihan ini dihadiri oleh Kepala Desa Tanjung Taruna dan perangkat desa. Selain itu pada saat kegiatan demplot dimulai peserta aktif berinteraksi mengajukan pertanyaan berkaitan dengan tanaman sayur-sayuran dan tanaman toga yang dapat dibudidayakan melalui sistem vertikultur, serta sumber daya alam yang dapat dijadikan kompos.

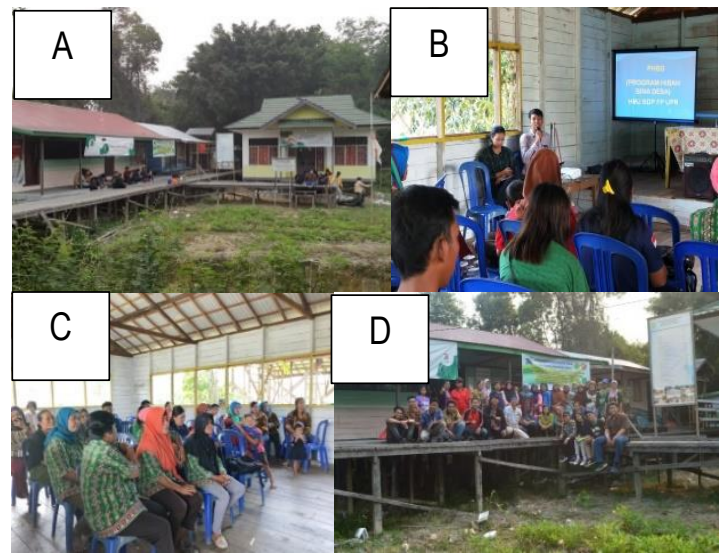

Gambar 2.

Sosialisasi Kegiatan: A. Tempat Pelaksanaan Kegiatan. B-C. Sosialisasi Program. D. Peserta Yang Mengikuti Kegiatan

\section{Pelaksanaan Kegiatan Pelatihan}

Pelatihan pembuatan kompos organik dengan teknologi yang sederhana dengan memanfaatkan tumbuhan yang terdapat di sekitar tempat tinggal mitra dan kotoran ternak, memberikan pengetahuan tentang manfaat kompos organik. Pada saat kegiatan diberikan demplot cara pembuatan kompos yang memanfaatkan limbah organik yang ada seperti gulma air dan kotoran ternak 
guna untuk memanfaatkan sumber daya yang ada secara optimal. Setelah demplot pembuatan kompos, masyarakat diarahkan ke pembuatan media tanam dengan komposisi yang baik untuk tanaman. Pelatihan pembuatan kompos dan pembuatan komposisi media tanam serta penanaman penyemaian disajikan pada Gambar 3. Proses pembuatan kompos disajikan pada Gambar 4.

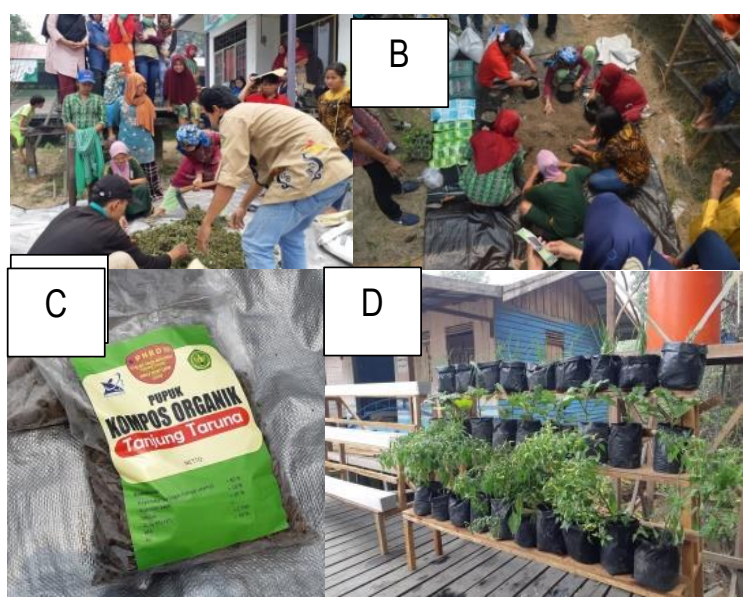

Gambar 3.

Pelaksanaan Pelatihan. A. Pembuatan Kompos. B. Pencampuran Komposisi Media Tanam. C. Hasil Kompos Desa Tanjung Taruna. D. Tanaman vertikultur

Pelatihan pembuatan tanaman secara vertikultur merupakan keinginan warga Desa Tanjung Taruna, karena melihat keadaan setempat apabila pasang ataupun musim hujan daerah ini sering tergenang air bahkan dapat menyebabkan banjir hingga sampai paling parah permukaan air sampai mengenai permukaan kayu rumah warga. Melalui teknik budidaya vertikultur kendala tersebut dapat diatasi, masyarakat memperoleh manfaat karena tidak perlu lagi membeli sayuran untuk memenuhi kebutuhan keluarga dan menghemat pengeluaran rumah tangga.

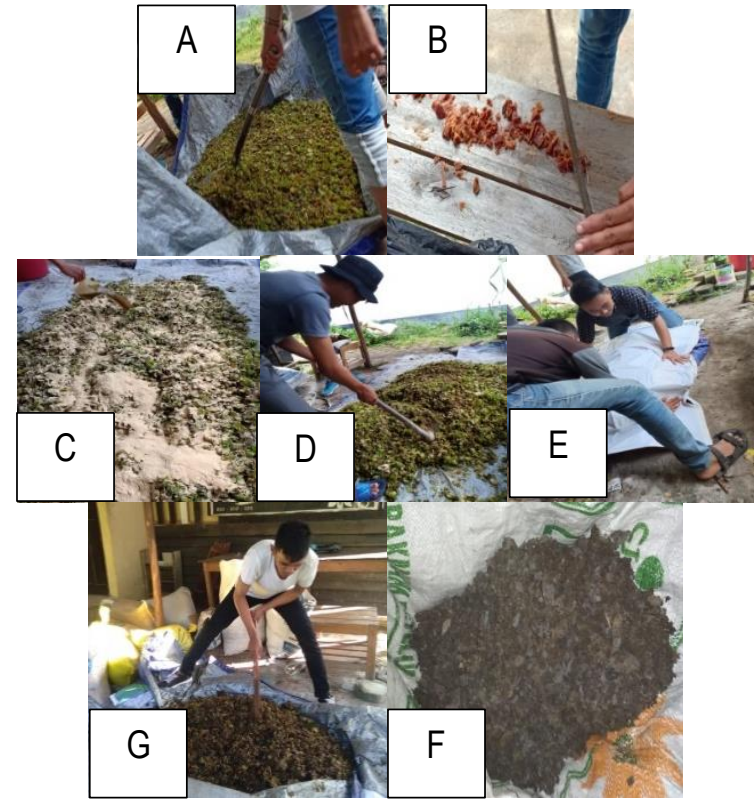

Gambar 4.

Pembuatan Kompos. A. Pencacahan Bahan. B. Penghalusan Gula Merah. C.

Pencampuran Bahan Lain. D. Pemerataan Bahan. E. Penutupan Kompos. F. Pembalikkan Kompos. G. Hasil Kompos

Pembuatan kompos dimulai dari pencacahan bahan utama seperti kayambang $35 \mathrm{Kg}$, setelah dicacah halus disiram dengan gula merah yang telah dihaluskan (1\% Dari Bahan Utama) + air, setelah itu mencampur semua bahan ((Dedak 5\%, Kotoran Ternak $10 \%$ + Air, EM4 0,25\% + Air) Dari Bahan Utama). Setelah dicampur lalu dibalik hingga rata sambil disiram dengan air 30\% dari bahan utama, setelah tercampur rata kompos ditutup untuk di inkubasi. Pembalikkan kompos selama 2 kali sehari dalam kurun waktu 1 bulan. Indikator kompos berhasil tidak berbau dan berwarna hitam kecoklatan, lalu diayak hingga halus. Kompos sudah siap dipakai/diaplikasikan.

\section{Evaluasi Kegiatan}

Pelaksanaan kegiatan program hibah bina desa ini diadakannya evaluasi kegiatan secara keseluruhan mulai dari perencanaan, persiapan, pelaksanaan hinga laporan akhir. Evaluasi ini guna untuk mengetahui serta mendata kelebihan dan kekurangan pada saat kegiatan. Diharapkan adanya evaluasi ini dapat memberikan masukan untuk 
kegiatan selanjutnya atau keberlanjutan dalam program hibah bina desa ini.

Hasil dari pelatihan antara lain dapat terlihat dari hasil kuesioner peserta, dimana $84,4 \%$ peserta sudah sangat tahu bahwa desa Tanjung Taruna memiliki sumberdaya alam berupa limbah kotoran ternak dan tumbuhan-tumbuhan air, $73,3 \%$ peserta sudah mengetahui teknik menanaman sayur dengan sistem vertikultur, 93,3\% peserta berkeinginan untuk membentuk sebuah kelompok usaha desa. Setelah mengikuti kegiatan sebagian besar peserta sangat merasakan manfaatnya dan memberi nilai positif, selanjutnya berdasarkan saran dan masukan peserta, perlu diadakan kegiatan lanjutan agar peserta dapat mengevaluasi hasil yang telah dijalankan dalam hal pembuatan kompos dan budidaya tanaman sistem vertikultur.

\section{Kesimpulan}

Masyarakat desa Tanjung Taruna antusias dalam mengikuti kegiatan pelatihan dari program hibah bina desa yang diberikan dan merasakan manfaatnya terhadap peningkatan ilmu pengetahuan mulai dari pengolahan kompos dengan memanfaatkan limbah organik, pencampuran komposisi media tanam serta budidaya tanaman secara vertikultur. Berdasarkan hasil evaluasi diketahui bahwa peserta menjadi bertambah pengetahuan, keterampilan dan wawasan dalam memanfaatkan hijauan yang tumbuh di rawa gambut menjadi kompos organik yang digunakan dalam budidaya sayuran dan toga sistem vertikultur dan dapat dijadikan tambahan penghasilan untuk dijual.

\section{Ucapkan Terima Kasih}

\begin{tabular}{|c|c|}
\hline \multicolumn{2}{|l|}{ Ucapan terima } \\
\hline kepada Direktorat & Kemahasiswaan, \\
\hline Direktorat & Pembelajaran dan \\
\hline Kemahasiswaan, & Kementrian Riset, \\
\hline $\begin{array}{l}\text { Teknologi dan Pendidi } \\
\text { mendanai kegiatan } P\end{array}$ & $\begin{array}{l}\text { likan Tinggi yang tela } \\
\text { Program Hibah Bir }\end{array}$ \\
\hline Himpunan & Mahasiswa Jurusan \\
\hline Budidaya Pertanian & Universitas Palangka \\
\hline
\end{tabular}

Raya di Desa Tanjung Taruna dengan nomor kontrak 1150/UN24/KM/2019.

\section{Daftar Pustaka}

Firmansyah, M. A. (2010). Teknik Pembuatan Kompos. Diakses dari kalteng.litbang.pertanian.go.id/ind/ima ges/data/teknik-kompos.pdf.

Nasrati. \& Pujiharti, Y. (2012). Budidaya Tanaman Obat Keluarga (Toga). Lampung: Balai Pengkajian Teknologi Pertanian Lampung.

Susila, A. D. (2006). P anduan Budidaya Tanaman Sayuran. Bogor: Departemen Agrronomi dan Hortikultura Institut Pertanian Bogor.

Trisnaningsih, U., Wahyuni, S. \& Nur, S. (2019). Pemanfaatan Lahan Pekarangan Dengan Tanaman Obat Keluarga. J.Pengabdian Dan Pemberdayaan Masyarakat. 3(2): 259-263. 